8 WAT again showed significantly reduced root numbers.

In general, the effects of herbicides on root length were similar to their effects on root number. In 1986, at 2 WAT, root lengths were reduced by bensulide, imazapyr, napropamide at $4.5 \mathrm{~kg} \cdot \mathrm{ha}^{-1}$, and sulfometuron treatments (Table 4). By 4 WAT, only bensulide, imazapyr, and napropamide at 4.5 $\mathrm{kg} \cdot \mathrm{ha}^{-1}$ continued to reduce root length; sulfometuron-treated sod no longer had reduced root length. At $8 \mathrm{WAT}$, napropamide at 4.5 $\mathrm{kg} \cdot \mathrm{ha}^{-1}$ had ceased to affect root length, but bensulide and imazapyr continued to suppress root elongation.

In 1987, bensulide, imazapyr, and napropamide at $2.2 \mathrm{~kg} \cdot \mathrm{ha}^{-1}$, and sulfometuron at 0.03 and $0.07 \mathrm{~kg} \cdot \mathrm{ha}^{-1}$ had reduced root length by 2 WAT. At 4 WAT, none of the herbicide treatments could be shown to reduce root length, possibly due to the large variation among the samples $(\mathrm{CV}=36 \%)$. At $8 \mathrm{WAT}$, bensulide and imazapyr were the only herbicide treatments that still reduced root length of the sod.

The results indicate that neither mature nor immature sod will exhibit visible effects from any of the herbicides at 8 WAT, except imazapyr, which had killed the aerial portion of the sod completely by that time. None of the herbicides reduced tensile strength of mature centipedegrass sod, and only imazapyr and bensulide affected strength of immature sod when applied after spring growth was well under way. However, results might be quite different if the same herbicides were applied in early spring, before centipedegrass has fully recovered from winter dormancy.

Although many of the herbicides causing reduced root length and/or number also visibly injured the turfgrass, the degree of injury was not consistent with respect to the degree of damage to rooting or tensile strength. However, since salability of sod is affected materially by the aesthetic quality of the top growth, visible injury may make certain herbicides unacceptable for use in sod production. Imazapyr and bensulide caused visible injury and/or reduced rooting enough' to preclude their use on centipedegrass sod within 8 weeks before expected harvest.

\section{Literature Cited}

Coats, G. E., 1975. Effect of preemergence herbicides on centipedegrass establishment. Proc. Southern Weed Sci. 28:81.

Cope, J. T., C.E. Evans, and H.C. Williams. 1980. Soil test fertilizer recommendations for Alabama crops. Ala. Agr. Expt. Sta. Cir. 251.

Jagschitz, J.A. 1977. Development and rooting of Kentucky bluegrass sod as affected by herbicides. Proc. 3rd Intl. Turf. Conf. p. 227-235.

Johnson, B.J. 1973. Establishment of centipedegrass and St. Augustinegrass with the aid of chemicals. Agron. J. 65:959-962.

Johnson, B.J. 1975. Herbicides for weed control during establishment of warm season turfgrasses. Coop. Ext. Serv. Univ. Ga. Leafit. 177.

Johnson, B.J. 1987. Turfgrass species response to herbicides applied postemergence. Weed Technol. 1:305-311.

Mitchell, C. H., and R. Dickens. 1979. Nitrogen fertilization and mowing height effects on tensile strength of bermudagrass sod. Agron. J. 71:1061-1062.

Shearman, R. C., E.J. Kinbacher, and D.H. Steinigger. 1979. Herbicide effects on sod transplant rooting of three Kentucky bluegrass cultivars. HortScience 14:282-283.

Troutman, B.C. and J.A. Jagschitz. 1971. Effects of preemergent herbicides on development and rooting of Kentucky bluegrass sod. Agron. Abstr. p. 50 .

Troutman, B. C., R.E. Frans, and J.W. King. 1974.
Evaluation of herbicides on ccntipedegrass. Ark. Farm Res. 23(6):10.

Turgeon, A.J. 1972. Preemerge herbicides and their effects on the turfgrass ecosystem. Proc. North Central Weed Cont. Conf. 27:62.

Turgeon, A. J., J.B. Beard, D.P. Martin, and W.F. Meggitt. 1974. Effects of successive applications of preemergence herbicides on turf. Weed Sci. 22:349-352.

Turner, D.L. and R. Dickens. 1987. Atrazine effects on tensile strength of centipedegrass sod. Agron. J. 79:3942.

HorTSCIENCE 25(5):544-546. 1990.

\title{
Respiratory Rates and Glycosidase Activities of Juice Vesicles Associated with Section-drying in Citrus
}

\author{
Jacqueline K. Burns \\ Citrus Research and Education Center, IFAS, Department of Fruit \\ Crops, University of Florida, 700 Experiment Station Road, Lake Alfred, \\ FL 33850
}

Additional index words. cell wall, Citrus paradisi, Citrus reticulate, granulation, oxygen uptake, tangelo, tangerine, grapefruit

Abstract. Oxygen uptake and glycosidase activities were examined in normal and granulated juice vesicles of several citrus fruit. Oxygen uptake was low in normal juice vesicles isolated from freshly harvested 'Lee' tangelos [Citrus reticulate Blanco Cv. Clementine $\times$ (Citrus paradisi Macf. $\mathrm{Cv}$. Duncan $\times$ Citrus reticulate Blanco $\mathrm{Cv}$. Dancy)] and stored 'Dancy' tangerine (C. reticulate Blanco) and 'Marsh' grapefruit (Citrus paradisi Macf.) $\left(35.7,17.9\right.$, and $11.6 \mu \mathrm{l} \mathrm{O}_{2} / \mathrm{hr}$ per $\mathrm{g}$ fresh weight, respectively), but was 2- to 3-fold higher in granulated juice vesicles. As severity of granulation increased in grape. fruit, $\mathrm{O}_{2}$ uptake increased. Oxygen uptake in normal and disordered juice vesicles of all citrus fruit examined was reduced to nondetectable levels with $0.1 \mathrm{mM}$ KCN and was insensitive to salicylhydroxamic acid. $\alpha-$ and $\beta$-galactosidase and $\alpha-$ and $\beta$-glucosidase activities were present in extracts of normal grapefruit juice vesicles $(123,214$, 51 , and $25 \mathrm{nmol} \cdot \mathrm{hr}^{-1} \cdot \mathrm{g}^{-1}$ fresh weight, respectively) and was 2 - to 3 -fold higher in extracts of granulated tissue. $\alpha$ - and $\beta$-mannosidase activities, nondetectable in normal juice vesicle extracts, were present in extracts from granulated tissue. The results suggest that increased metabolic activity occurs in granulated juice vesicles and the energy produced may be used to support cell wall synthesis and modification. Increases in $\mathrm{O}_{2}$ uptake and glycosidase activities correlate well with observed symptoms of section-drying in citrus.

Section-drying is a late-harvest physiological disorder of citrus fruit, such as 'Valencia' orange (Bartholomew et al., 1941) and many tangerine and grapefruit cultivars (Nakajima, 1976; Burns and Achor, 1989). The disorder is characterized by the hardening, or granulation, of the juice vesicles at the stem and/or the stylar end of the fruit segment. In grapefruit, affected vesicles eventually discolor and collapse. In some cases, vesicles may collapse without undergoing granulation. Section-drying can occur in fruit that remain on the tree late in the season,

Received for publication 28 Aug. 1989. Florida Agricultural Experiment Station Journal Series no. R-00146. The cost of publishing this paper was defrayed in part by the payment of page charges. Under postal regulations, this paper therefore must be hereby marked advertisement solely to indicate this fact. but becomes more severe during storage of late-harvest fruit. Some cultivars, such as 'Lee' tangelos, can often show symptoms of section-drying before optimum maturity is attained.

Anatomical investigations have shown extensive cell wall thickening and scattered secondary wall formation in internal parenchyma and epidermal cells of granulated juice vesicles isolated from late-harvest citrus fruit (Burns and Achor, 1989; Shomer et al., 1989). Lignin deposition within cells of granulated vesicles has also been detected histochemically in grapefruit (Burns and Achor, 1989), as well as chemically in pummelo (Shomer et al., 1989). Loss of soluble sugars and acidity occurs in juice vesicles associated with granulation (Bartholomew et al., 1941; Sinclair and Jolliffe, 1961; Gilfillan and Stevenson, 1977; El-Zeftawi, 1978; Shomer et al., 1989). A decrease in the 
Table 1. Oxygen uptake in normal and granulated juice vesicles of grapefruit, tangerine, and tangelo fruit. Data presented are the means $( \pm \mathrm{SE})$.

\begin{tabular}{|c|c|c|}
\hline \multirow[b]{2}{*}{ Juice vesicle type } & \multicolumn{2}{|c|}{$\begin{array}{c}\mathrm{O}_{2} \text { uptake } \\
\left(\mu \mathrm{l} \mathrm{O}_{2} / \mathrm{hr} \text { per } \mathrm{g} \text { fresh wt }\right)^{2}\end{array}$} \\
\hline & No inhibitor & +10 mM SHAM \\
\hline \multicolumn{3}{|l|}{ Marsh grapefruit } \\
\hline Normal & $11.6(3.1)$ & $13.8(1.3)$ \\
\hline Granulated & $37.5(1.3)$ & $37.9(4.5)$ \\
\hline Granulated-collapsed & $74.1(4.9)$ & $69.8(5.2)$ \\
\hline \multicolumn{3}{|l|}{ Dancy tangerine } \\
\hline Normal & $17.9(2.2)$ & $16.5(2.7)$ \\
\hline Granulated & $37.9(3.1)$ & $40.2(2.2)$ \\
\hline \multicolumn{3}{|l|}{ Lee tangelo } \\
\hline Normal & $35.7(6.7)$ & $31.2(3.6)$ \\
\hline Granulated & $74.1(7.6)$ & $67.9(5.4)$ \\
\hline
\end{tabular}

${ }^{2}$ Normal, granulated, and granulated-collapsed (grapefruit) different for each citrus fruit, paired $t$ test, $P<0.005$

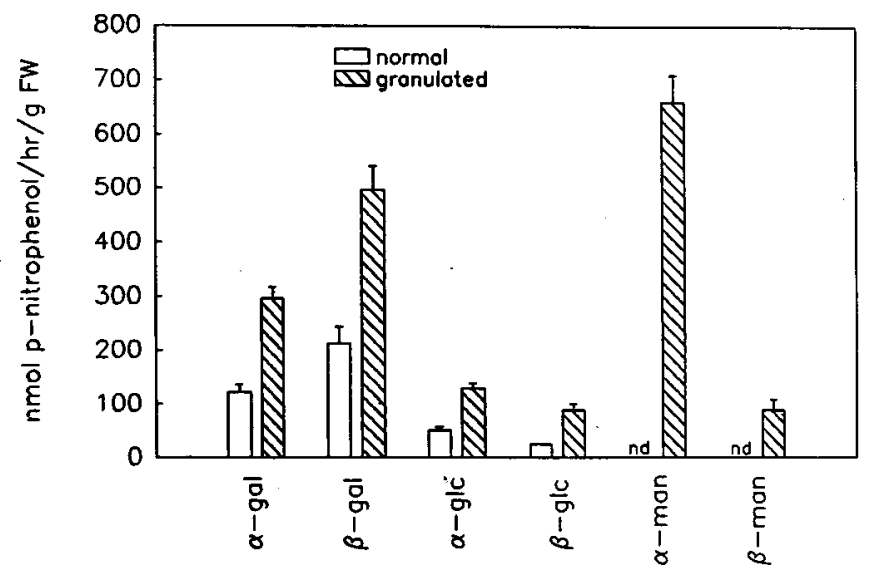

Fig. 1. Glycosidase activities present in extracts of normal and granulated juice vesicles of 'Marsh' grapefruit. Data plotted are the means + SD. $\alpha$-gal, $\beta$-gal, $\alpha$-glc, $\beta$-glc, $\alpha$-man, and $\beta$-man are $\alpha-$ galactosidase, $\beta$-galactosidase, $\alpha$-glucosidase, $\beta$-ducosidase, $\alpha$-mannosidase, and $\beta$-mannosidase. respectively. $\mathrm{nd}=$ None detected.

amount of arabinose, galactose, mannose, and rhamnose was measured in the insoluble fraction of extracts from granulated pummelo tissue. Increased amounts of xylose and glucose (Shomer et al., 1989), as well as hemicellulose, cellulose, and pectin (Hwang et al., 1990), have also been reported in the insoluble component.

Previous research has, therefore, indicated the occurrence of cell wall synthesis and modification of cell wall neutral sugars in cells of granulated juice vesicles of senescing citrus,fruit. Comparison of trends in the soluble and insoluble fractions of normal and granulated juice vesicles suggests that deposition and modification of cell wall components occur at the expense of soluble sugars and acids within the iuice vesicle. To test this hypothesis, $\mathrm{O}_{2}$ uptake rates were examined in normal and granulated juice vesicles isolated from several citrus fruit. The results provide evidence for the existence of adequate metabolic activity to support active cell wall synthesis and modification in granulated juice vesicles of senescing citrus fruit. In addition, several glycosidase activities were measured, since previous work has shown a possible role for glycosidases in cell wall modification and metabolism in fruit tissues (Bartley, 1974; Ahmed and Labavitch, 1980; Pressey, 1983). A role for glycosidases as possible means of insoluble fraction modification is suggested.
Plant material. Fruit from 'Lee' tangelo and 'Dancy' tangerine were harvested from groves near Lake Wales in Florida and 'Marsh' grapefruit from the Indian River district of Florida. Tangerines and grapefruit were washed, fungicide applied (1000 ppm thiabendazole), waxed (FMC-Flavorseal 93), and stored to ensure development of sectiondrying ( 2 and 6 weeks, respectively, at 15C), whereas tangelos were tested directly after harvest.

Oxygen uptake. Individual juice vesicles were removed from the stem or the stylar portion of tangelo, tangerine, and grapefruit fruit segments and divided into normal and granulated categories based on visual appearance. Normal vesicles were obtained from normal or section-dried fruit. Six juice vesicles were placed in the chamber of a YSI $\mathrm{O}_{2}$ monitor (Yellow Springs Instrument Co. Yellow Springs, Ohio) that contained $6 \mathrm{ml}$ distilled water. After a 5-rein equilibration period, $\mathrm{O}_{2}$ uptake was monitored at $25 \mathrm{C}$ with an $\mathrm{O}_{2}$ electrode for $20 \mathrm{~min}$. Uptake was linear for more than $1 \mathrm{hr}$. Inhibitors were added after a consistent $\mathrm{O}_{2}$ uptake trace was observed. Potassium cyanide $(\mathrm{KCN})$ or salicylhydroxamic acid (SHAM) (Sigma, St. Louis) was added to the reaction system at 0.1 to $10 \mathrm{~mm}$ Water, with and without inhibitors, and boiled tissue were used as controls. One measurement was made per fruit (six vesicles/fruit), and at least 10 fruit were used per cultivar. Oxygen uptake in juice vesicles was expressed in microliters $\mathrm{O}_{2}$ /hour per gram fresh weight.

Glycosidase extraction. Glycosidases were extracted from normal and granulated juice vesicles of grapefruit by the method of Pressey (1983), with some modification. Juice vesicles were homogenized in cold distilled $\mathrm{H}_{2} \mathrm{O}\left(100 \mathrm{~g}\right.$ tissue $: 150 \mathrm{ml} \mathrm{H}_{2} \mathrm{O}$ ). All subsequent steps were carried out at $4 \mathrm{C}$. The homogenate was stirred for 30 rein, then brought to $1 \mathrm{M}$ salt by addition of solid $\mathrm{NaCl}$. After the $\mathrm{pH}$ was adjusted to 6.0 with $1 \mathrm{~N}$ $\mathrm{HCl}$, the homogenate was stirred for an additional hour. The homogenate was clarified by centrifugation at $10,000 \times \mathrm{g}$ for $20 \mathrm{~min}$. Solid $\left(\mathrm{NH}_{4}\right)_{2} \mathrm{SO}_{4}$ was added to the supernatant to $\approx 65 \%$ saturation over $2 \mathrm{hr}$. The precipitant was collected by centrifugation and then dialyzed overnight against two changes of $0.1 \mathrm{M} \mathrm{NaCl}$. Insoluble material, formed during dialysis, was removed by centrifugation. The supernatant was lyophilized and stored at $-15 \mathrm{C}$. When needed, lyophilized powder was resuspended in $0.05 \mathrm{M}$ sodium acetate buffer, pH 5.0 (10 mg powder/ml), and centrifuged. The resulting supernatant was considered the enzyme solution and assayed for activity.

Enzyme assays. Glycosidase activities were assessed by the use of the appropriate p-nitrophenyl glycoside substrate (Pressey, 1983) (Sigma). For example, the reaction mixture for determination of $\beta$-galactosidase (EC 3.2 .1 .23 ) activity contained $1.0 \mathrm{ml}$ of 0.05 M sodium acetate buffer ( $\mathrm{pH} 5.0), 0.1 \mathrm{ml}$ of enzyme solution, and $0.4 \mathrm{ml}$ of $3.5 \mathrm{mM} p$ nitrophenyl- $\beta$-galactoside (final concentration). After incubation at $40 \mathrm{C}$ for 15 rein, the reaction was terminated by the addition of $2.0 \mathrm{ml}$ of $0.2 \mathrm{M} \mathrm{Na}_{2} \mathrm{CO}_{3}$, and the liberated p-nitrophenol was measured by absorbance at $405 \mathrm{~nm}$. Enzymatic activity was linear for more than $1 \mathrm{hr}$, with respect to substrate, and expressed in $\mu \mathrm{mol}$ p-nitrophenol liberated/ hour per gram fresh weight. Protein concentration was estimated by the method of Bradford (1976), with bovine serum albumin as standard.

The rate of $\mathrm{O}_{2}$ uptake in granulated juice vesicles of tangelo, tangerine, and grapefruit was two to three times greater than in normal juice vesicles isolated from similar segment positions in the same fruit (Table 1). The increase in respiratory rate occurred whether expressed on a fresh-or dry-weight basis (data not shown). No significant difference was detected in $\mathrm{O}_{2}$ uptake rate in juice vesicles due to stem or stylar position within the segment in normal or granulated tissue. Oxygen uptake was similar in normal juice vesicles isolated from either granulated or unaffected fruit. A similar increase in $\mathrm{O}_{2}$ uptake was measured in granulated juice vesicles of 'Valencia' orange (data not shown). As intensity of granulation increased (granulatedcollapsed) in grapefruit, a greater than 6-fold increase in the rate of $\mathrm{O}_{2}$ uptake was observed, compared to normal tissue. $\mathrm{No} \mathrm{O}_{2}$ uptake was measured in boiled tissue. Concentrations of SHAM as high as $10 \mathrm{mM}$ resulted in no inhibition of $\mathrm{O}_{2}$ uptake in normal 
or disordered vesicles. No detectable $\mathrm{O}_{2}$ uptake by juice vesicles was measured in the presence of $0.1 \mathrm{mM} \mathrm{KCN}$ (data not shown).

Higher $\mathrm{O}_{2}$ uptake rates were measured in normal and granulated juice vesicles from freshly harvested tangelos, whereas those removed from stored tangerines and grapefruit had significantly lower $\mathrm{O}_{2}$ uptake rates. Although differences in respiration maybe due to genotype, a decreasing pattern of respiration in late-harvest and stored fruit has been reported previously (Chakawar and Singh, 1977b).

Total recovered protein was $>3$-fold higher in granulated than in normal juice vesicles of grapefruit $(61.3 \mu \mathrm{g}$ and $20.1 \mu \mathrm{g}$ protein/ $\mathrm{g}$ fresh weight, respectively). Measured activities of $\alpha$-galactosidase (EC 3.2.1.22), $\beta$ galactosidase (EC 3.2.1.23), $\alpha$-glucosidase (EC 3.2.1.20), and $\beta$-glucosidase (EC 3.2.1.21) were two to three times higher in granulated vesicles than normal ones (Fig. 1 ). Both $\alpha$-and $\beta$-mannosidase activities (EC 3.2.1.24 and 3.2.1.25, respectively), nondetectable in normal juice vesicles, rose to high levels in' disordered tissue, especially $\alpha$-mannosidase. No $\alpha$-arabinosidase (EC 2.1.55) or polygalacturonase (EC 3.2.1.15) was detected in extracts of normal or granulated juice vesicles of grapefruit. Pectinesterase (EC 3.1.11) activity, not determined here, has been reported to decrease in granulated tissue (Chakawar and Singh, 1977b; Gilfillan and Stevenson, 1977).

Increased respiration rates have been demonstrated in whole fruit of oranges (Bartholomew et al., 1941) and fruit segments and juice vesicles of mandarin types (Nakajima, 1976; Chakawar and Singh, 1977b) that show symptoms of granulation. This report provides evidence that increased respiration of individual, granulated juice vesicles occurs in other citrus fruit as well. The increase in $\mathrm{O}_{2}$ uptake, and therefore apparent respiration rate, in granulated juice vesicles suggests an increase in the general metabolic rate. Complete inhibition with KCN (an inhibitor of cytochrome oxidase) and, conversely, insensitivity to SHAM (an inhibitor of the alternate oxidase) indicates that respiration is coupled to ATP formation (Solomos, 1988). The energy produced by the elevated respiratory activity may be used to support processes such as cell wall synthesis and modification in juice vesicles undergoing granulation. Cell wall synthesis and modification during granulation of juice vesicles has been implicated in anatomical studies with grapefruit (Burns and Achor, 1989) and pummelo (Shomer et al., 1989) and in chemical studies demonstrating accumulation of cell wall-associated materials (Bartholomew et al., 1941; Sinclair and Jolliffe, 1961; Chakawar and Singh, 1977a; Gilfillan and Stevenson, 1977; Shomer et al., 1989). The 2- to 3-fold increase in the cellulose, hemicellulose, and pectin fraction previously measured in granulated juice vesicles (Hwang et al., 1990) suggests that the ATP produced by the similar increase in respiratory rate may be used to construct and modify cell walls.

Glycosidase activities have been detected in many growing and senescing plant tissues (Bolwell, 1988), but, despite the ability to hydrolyze their respective linkages, their functions remain largely unknown. Studies on the activities of glycosidases in fruit of apple (Bartley, 1974), tomato (Pressey, 1983), and pear (Ahmed and Labavitch, 1980) have suggested a role in cell wall metabolism. In granulated juice vesicles of pummelo, decreases in rhamnose, arabinose, mannose, and galactose, and increases in xylose and glucose in the insoluble cell wall fraction (Shomer et al., 1989) indicate that modification of the cell wall has occurred. Modification of the neutral sugar side chains in the pectin fraction in granulated juice vesicles of grapefruit has also been reported (Hwang et al., 1990). The significant increases in measurable glycosidase activities in granulated juice vesicles of grapefruit imply a role for these enzymes in cell wall modification in this tissue. The suggestion is strengthened by the observation that $>80 ? \%$ of the total activity of several glycosidases in granulated grapefruit extracts are found in the bound, or high ionic strength, extractable fraction (unpublished data). There are, however, other hydrolytic functions of glycosidases not directly associated with the cell wall, such as glycolipid, glycoprotein, and reserve oligosaccharide metabolism (Bolwell, 1988). Further work in the area of cell wall structural analysis is needed to clarify the importance of these enzymes in granulation.
Literature Cited

Ahmed, A.E.R. and J.M. Labavitch. 1980. Cell wall metabolism in ripening fruit. L Cell wall changes in ripening 'Bartlett' pears. Plant Physiol. 65:1009-1113.

Bartholomew, E. T., W.B. Sinclair, and F.M. Turrell. 1941. Granulation of Valencia oranges. Univ. California Agr. Expt. Sta. Bul. 647.

Bartley, I.M. 1974. (3-Galactosidase activity in ripening apples. Photochemistry 13:132-135.

Bolwell, G.P. 1988. Synthesis of cell wall components: Aspects of control. Photochemistry 27:1235-1253.

Bradford, M.M. 1976. A rapid and sensitive method for the quantification of microgram quantities of protein using the principle of protein dye binding. Anal. Biochem. 72:248-254.

Burns, J.K. and D.S. Achor. 1989. Cell wall changes associated with "section-drying" in stored late-harvested grapefruit. J. Amer. Soc. Hort. Sci. 114:283-287.

Chakawar, V.R. and R. Singh. 1977a. Studies on citrus granulation. I. Physical and quality aspects of granulation. Haryana J. Hort. Sci. 6:128-131.

Chakawar, V.R. and R. Singh. 1977b. Studies on citrus granulation. 11. Physiological and biochemical aspects of granulation. Haryana J. Hort. Sci. 6:132-135.

El-Zeftawi, B.M. 1978. Factors affecting granulation and quality of late-picked Valencia oranges. J. Hort. Sci. 53:331-337.

Gilfillan, I.M. and J.A. Stevenson. 1977. postharvest development of granulation in South African export oranges. Proc. Intl. Soc. Citriculture 1:299-303.

Hwang, Y.-S., D.J. Huber, and L.G. Albrigo. 1990. Comparison of cell wall components in normal and disordered (granulation and vesicle collapse) juice vesicles of grapefruit. J. Amer. Soc. Hort. Sci. 115:281-287.

Nakajima, Y. 1976. Studies on dry juice sacs of Hyuganatsu (Citrus tamurana Hort. ex Tanaka) in late stages of fruit development. J. Jpn. Soc. Hort. Sci. 44:338-346.

Pressey, R. 1983. $\beta$-Galactosidases in ripening tomatoes. Plant Physiol. 71:132-135.

Shomer, I., E. Chalutz, R. Vasiliver, E. Lomanice, and M. Berman. 1989. Sclerification of juice sacs in pummelo (Citrus grandis) fruit. Can. J. Bet. 67:625-632.

Sinclair, W.B. and V.A. Jolliffe. 1961. Chemical changes in the juice vesicles of granulated Valencia oranges. J. Food Sci. 26:276-282.

Solomos, T. 1988. Respiration in senescing plant organs: Its nature, regulation, and physiological significance, p. 111-145. In: L.D. Nooden and A.C. Leopold (eds.). Senescence and aging in, plants. Academic, San Diego. 